\title{
Low-dose eribulin reduces lung metastasis of osteosarcoma in vitro and in vivo
}

\author{
Kenta Watanabe ${ }^{1,2, *}$, Yoshihiro Yui ${ }^{2, *}$, Satoru Sasagawa ${ }^{2}$, Kayo Suzuki ${ }^{1}$, Masahiko \\ Kanamori $^{3}$, Taketoshi Yasuda ${ }^{1}$ and Tomoatsu Kimura ${ }^{1}$ \\ ${ }^{1}$ Department of Orthopedic Surgery, University of Toyama, Toyama, Japan \\ ${ }^{2}$ Research Institute, Nozaki Tokushukai Hospital, Osaka, Japan \\ ${ }^{3}$ Department of Human Science, University of Toyama, Toyama, Japan \\ *These authors contributed equally to this work \\ Correspondence to: Yoshihiro Yui, email: yoshihiro.yui@tokushukai.jp \\ Keywords: eribulin; osteosarcoma; metastasis; LM8; circulating tumor cells \\ Received: September 07,2018 Accepted: December 20,2018Ｐublished: January 04, 2019
}

Copyright: Watanabe et al. This is an open-access article distributed under the terms of the Creative Commons Attribution License 3.0 (CC BY 3.0), which permits unrestricted use, distribution, and reproduction in any medium, provided the original author and source are credited.

\section{ABSTRACT}

Lung metastasis markedly reduces the prognosis of osteosarcoma. Moreover, there is no effective treatment for lung metastasis, and a new treatment strategy for the treatment of osteosarcoma lung metastasis is required. Therefore, in this study, we investigated the suppressive effect of the microtubule inhibitor eribulin mesylate (eribulin) on lung metastasis of osteosarcoma. At concentrations $>$ proliferation IC $_{50}$ eribulin induced cell cycle arrest and apoptosis in a metastatic osteosarcoma cell line, LM8. However, at concentrations < proliferation $\mathrm{IC}_{50}$ ( (low dose), eribulin changed cell morphology and decreased LM8 migration. Low eribulin concentrations also reduced directionality during migration, peripheral localization of adenomatous polyposis coli protein, and turnover of focal adhesions. In a three-dimensional collagen culture system, low eribulin concentrations inhibited tumor cell proliferation and colony formation. Higher doses of eribulin administered on a standard schedule inhibited lung metastasis and primary tumor growth in a murine osteosarcoma metastasis model. Frequent low-dose eribulin administration $(0.3 \mathrm{mg} / \mathrm{kg}$ every 4 days $\times 4)$ effectively inhibited lung metastasis but had little effect on primary tumor growth. Overall, our results indicate that eribulin could reduce osteosarcoma lung metastasis.

\section{INTRODUCTION}

Osteosarcoma is the most common malignant bone tumor among children and adolescents. The prognosis of osteosarcoma has been poor over the past thirty years. The overall five-year survival rates without and with metastasis at the time of diagnosis are $60-70 \%$ and $15-$ $20 \%$, respectively $[1,2]$ mainly because there are few therapeutic options for lung metastasis of osteosarcoma. The most effective treatment option so far is neoadjuvant chemotherapy developed in the 1980s and consisting of high-dose methotrexate, doxorubicin, and cisplatin (MAP) $[3,4]$. Unfortunately, no clinical trials for metastasis inhibition have improved the outcome of patients with osteosarcoma, especially for those who respond poorly to MAP regimens $[5,6]$. Therefore, a new treatment strategy for osteosarcoma lung metastasis is required.
Several factors contribute to metastasis from primary tumors to remote organs. Many anti-metastatic agents targeting these processes are under development. Cell migration is a major target for metastasis treatment. It involves tumor cell invasion into surrounding tissues, intravasation into blood vessels, and extravasation into metastatic organs [7]. Metastatic colonization by circulating tumor cells (CTC) has recently emerged as a new target for metastasis treatment. The mechanism of CTC colonization includes the evasion of immune surveillance, adaptation to the metastatic microenvironment, and survival as dormant tumor cells [8]. However, only a few clinical trials on molecular targeted anti-metastasis therapies have demonstrated efficacy. The specific difficulty to find a new treatment strategy for lung metastasis associated with osteosarcoma is that there are few targetable mutations or highly 
reproducible metastatic murine models available to test anti-metastatic agent efficacy [9].

Microtubule targeting agents (MTAs) are excellent anticancer drugs because they inhibit cell division by suppressing microtubule dynamics [10-12]. Eribulin mesylate (eribulin) is an MTA, which destabilizes microtubules by targeting microtubule plus ends and inhibiting microtubule elongation [13-17]. Like other MTAs, its main anti-tumor actions are the suppression of mitotic spindle organization and the induction of apoptosis. Eribulin also induces mesenchymal-epithelial transition and suppresses cell migration [18-20]. Unlike other anti-microtubule agents that inhibit angiogenesis, eribulin remodels abnormal tumor vasculature. It is used as a second- or third-line treatment for recurrent breast tumor and malignant soft tissue sarcoma. However, the Children's Oncology Group phase II eribulin trial for relapsed osteosarcoma failed, showing no efficacy on tumor shrinkage [21, 22], although eribulin suppressed tumors in osteosarcoma xenografts [23].

There are limited preclinical and clinical data for the suppressive effects of eribulin on metastasis. In preclinical experiments, eribulin only suppressed lung metastasis of a breast cancer cell line in a mouse tail vein injection model [24]. To date, it is unknown how eribulin suppresses metastasis. The results of phase III trials of eribulin for both metastatic breast cancer $[25,26]$ and advanced soft tissue sarcoma [27] indicated that eribulin prolonged overall survival but seldom extended progression-free survival. These results strongly suggest that eribulin suppresses metastasis progression even when it does not significantly suppress primary tumor growth.

To develop a new treatment option for osteosarcoma lung metastasis, we investigated whether eribulin inhibited lung metastasis of osteosarcoma in a murine metastasis model. Low concentrations of eribulin were anti-metastatic by means other than the induction of cell cycle arrest and apoptosis. Frequent low-dose eribulin administration inhibited lung metastasis of osteosarcoma, indicating the potential of eribulin in the reduction of lung metastasis of osteosarcoma.

\section{RESULTS}

\section{Inhibition of lung metastasis by eribulin in a murine model}

We first investigated whether eribulin inhibits osteosarcoma lung metastasis in a mouse model using a clinical administration schedule. According to the package insert, eribulin was clinically administered at $1.4 \mathrm{mg} / \mathrm{m}^{2}$ on day 1 and day 8 . The pharmacokinetics data for humans and mice revealed that $1 \mathrm{mg} / \mathrm{kg}$ eribulin administered to mice had similar pharmacokinetics to $1.4 \mathrm{mg} / \mathrm{m}^{2}$ eribulin in humans. Thus, we administered eribulin at $1 \mathrm{mg} / \mathrm{kg}$ every 7 days $\times 2$ in the osteosarcoma metastatic model
(Figure 1A). The body weights of mice in the treatment group were significantly lower than those in the control group (Figure 1B). Eribulin treatment significantly suppressed primary tumor growth (Figure 1C) and induced apoptosis in tumor cells (Figure 1D). We assessed lung metastasis by counting the metastatic foci (Figure 1E) and measuring their area in tissue sections (Figure $1 \mathrm{~F}$ top). Eribulin clearly reduced lung metatasis. Histological images showed that in the control group, large metastatic foci infiltrated the lung parenchyma. In contrast, small metastatic foci were solitary within the normal alveolar structure in the treatment group (Figure 1F bottom). To determine whether eribulin reduced CTCs, blood samples were collected and cultured to form colonies. The colony number significantly decreased in the treatment group (Figure $1 \mathrm{G}$ ) relative to that in the control group. These results indicate that eribulin reduced primary tumor growth and lung metastasis of osteosarcoma.

\section{Suppression of CTC appearance by the low- concentration phase of eribulin}

It has been reported that the pharmacokinetics of eribulin intravenously administered at $1 \mathrm{mg} / \mathrm{kg}$ presents as a brief high-concentration phase, which surged to $\geq 100 \mathrm{nM}$, followed by a long low-concentration phase, which stabilized at $\sim 10 \mathrm{nM}$ for one week [28, 29]. During the long low-concentration phase, eribulin might be bioavailable enough to inhibit metastasis by suppressing tumor cell survival in the blood. To examine the correlation between CTC appearance and eribulin pharmacokinetics, we conducted a time course analysis of CTC appearance representing the rate of CTC in 40 $\mu \mathrm{L}$ mouse blood (Supplementary Figure 1A). The CTC appearance rate in the treatment group decreased 10 days after eribulin injection but eventually increased to the level observed in the control group (Supplementary Figure 1B). Therefore, the suppression of CTC appearance continued during the long low-concentration phase of eribulin.

\section{Mitotic arrest and apoptosis by high concentrations of eribulin}

We speculated that eribulin exerted anti-metastatic action through different mechanisms in the brief highconcentration and long low-concentration phases. We therefore tried to elucidate the contribution of each phase to the reduction of metastasis. We first examined the $\mathrm{IC}_{50}$ of proliferation for LM8 and Dunn cells. There was no difference in $\mathrm{IC}_{50}$ concentration between the two osteosarcoma cell lines (LM8: $22.8 \mathrm{nM}$; Dunn: $21.5 \mathrm{nM}$ ) (Figure 2A). They were both pharmacokinetically higher than those of the low-concentration phase as well as those previously reported for breast cancer and soft tissue sarcoma $[17,20]$. Flow cytometry showed that early apoptosis significantly increased after $24 \mathrm{~h}$ treatment with $50 \mathrm{nM}$ 
A

LM8: $5 \times 10^{6}$ cells / mouse sc injection
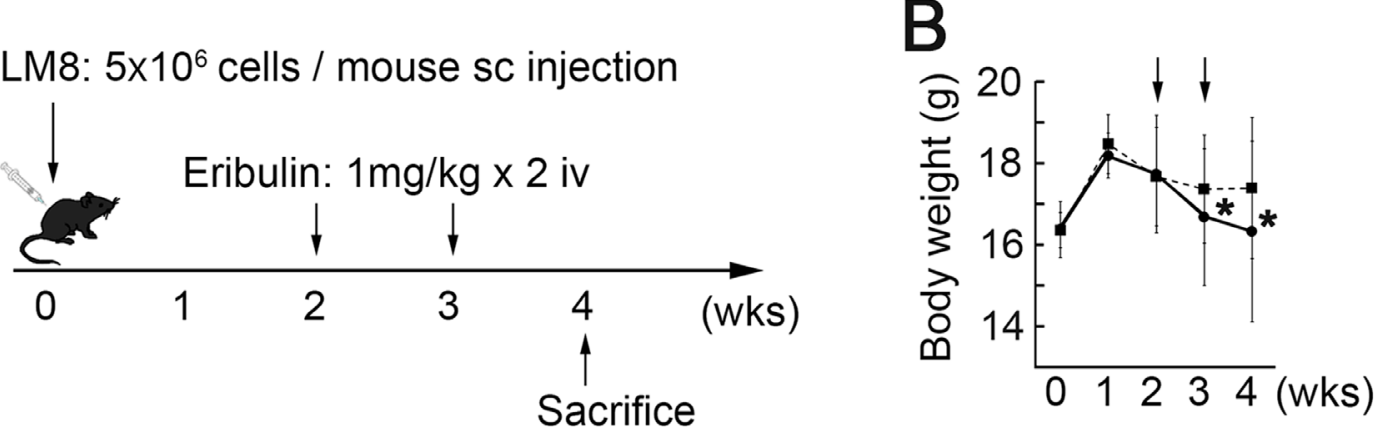

C
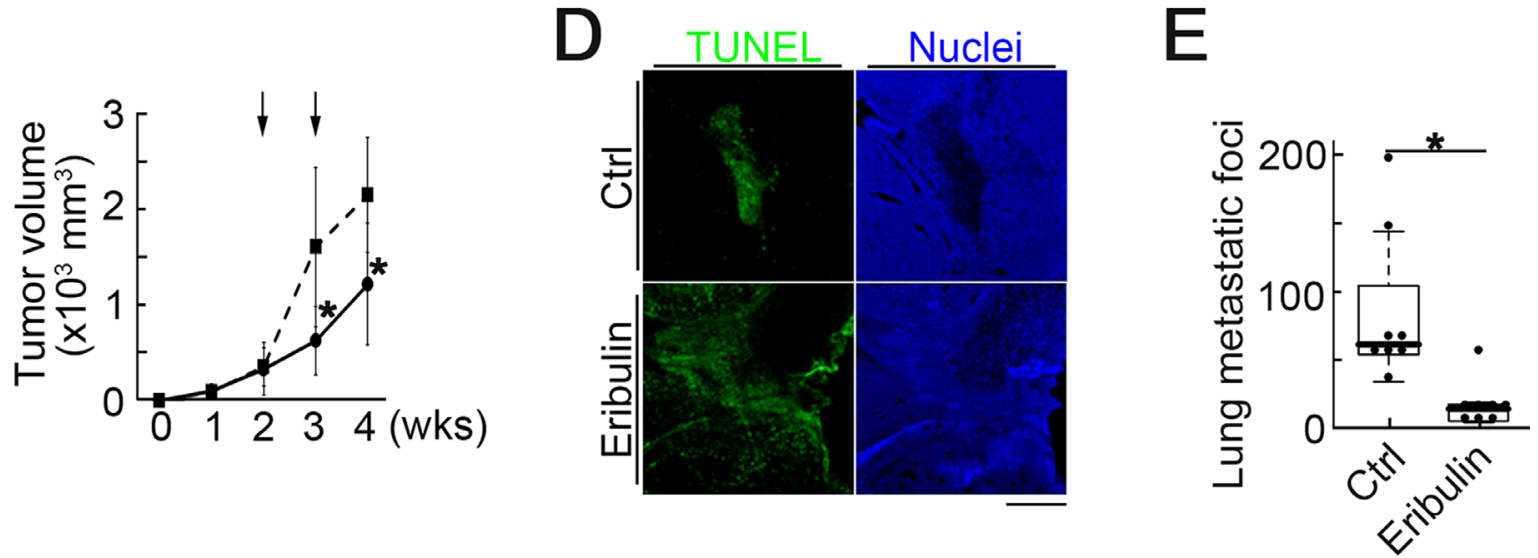

$\mathbf{F}$

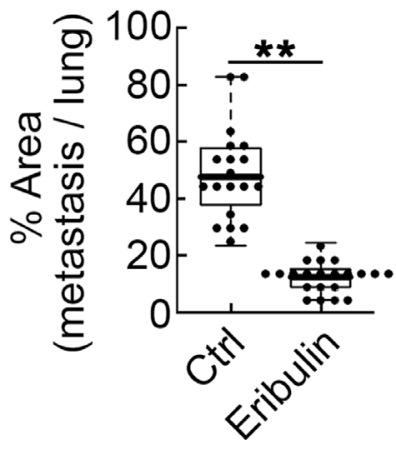

G
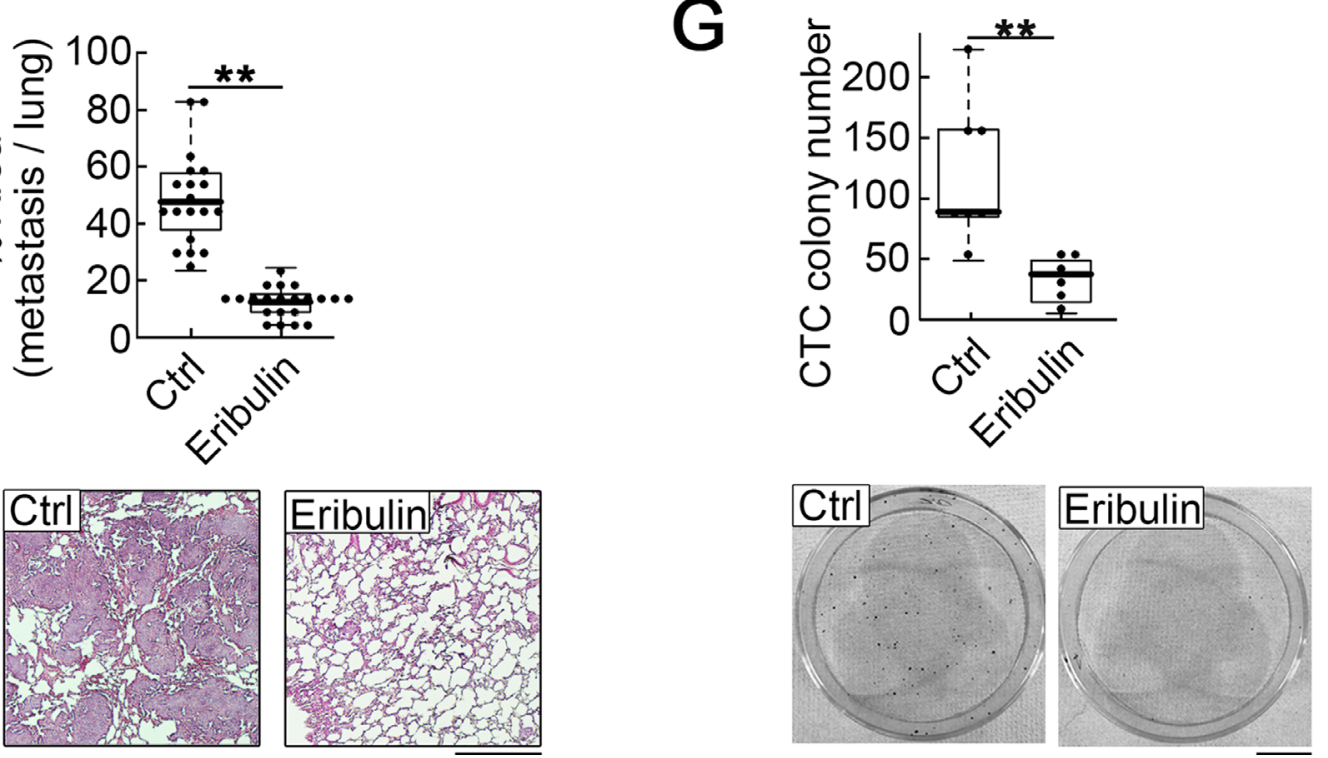

Figure 1: Intravenous eribulin injection in a syngeneic mouse osteosarcoma metastasis model. (A) Experimental schedule. Sixteen mice were divided into two groups: 1) untreated controls (eight mice); 2) treated with eribulin at $1 \mathrm{mg} / \mathrm{kg} / \mathrm{week}$ for two weeks (eight mice). (B) Body weights of mice in the control (dotted line) and treatment (solid line) groups. Values are mean $\pm \operatorname{SEM}(n=5) .{ }^{*} P<0.05$. (C) Eribulin inhibited primary tumor growth. Arrows: injection of PBS or eribulin. Values are mean \pm SEM $(n=5)$. Solid line: treatment group; dotted line: control group. Tumor volumes were significantly lower in the treatment than in the control group at days 21 and 28 . ${ }^{*} P<$ 0.05. (D) Representative fluorescence images of primary tumors in the control and treatment groups stained for Tunel (green) and nucleus (blue). Scale bar: $500 \mu \mathrm{m}$. (E) Number of metastatic foci in the lungs was significantly lower in the treatment than in the control group. Median, quartiles, and highest and lowest values are indicated on the box-and-whisker plots. ${ }^{*} P<0.05$. (F) Ratio of metastatic area to total lung area was significantly lower in the treatment than in the control group. Median, quartiles, and highest and lowest values are indicated on the box-and-whisker plots (top). Representative H\&E-stained sections of pulmonary metastasis in the control (bottom left) and treatment (bottom right) groups are shown. Scale bar: $500 \mu \mathrm{m}$. ${ }^{* *} P<0.01$. (G) CTC colony number per $40 \mu \mathrm{L}$ of peripheral blood. Median, quartiles, and highest and lowest values are indicated on the box-and-whisker plots (top). Images of CTC colonies in the control (bottom left) and treatment (bottom right) groups. Scale bar: $1 \mathrm{~cm} .{ }^{* *} P<0.01$. 
eribulin. The slight increase in 7-AAD+/annexin- population with $50 \mathrm{nM}$ eribulin might suggest that eribulin also induced non-apoptotic cell death. On the other hand, apoptosis was not detected with $10 \mathrm{nM}$ eribulin, even after $72 \mathrm{~h}$ (Figure 2B; Supplementary Figure 2A). The cell cycle analyses showed that G2/M arrest was induced by $12 \mathrm{~h}$ treatment with $50 \mathrm{nM}$ eribulin but not by long-term treatment (72 h) with $10 \mathrm{nM}$ eribulin (Figure 2C; Supplementary Figure 2B). We also examined whether eribulin induced senescence in LM8 cells. No senescence was detected with $12 \mathrm{~h}$ treatment with eribulin (Supplementary Figure 3A). Even longterm treatment with eribulin did not induce senescence;
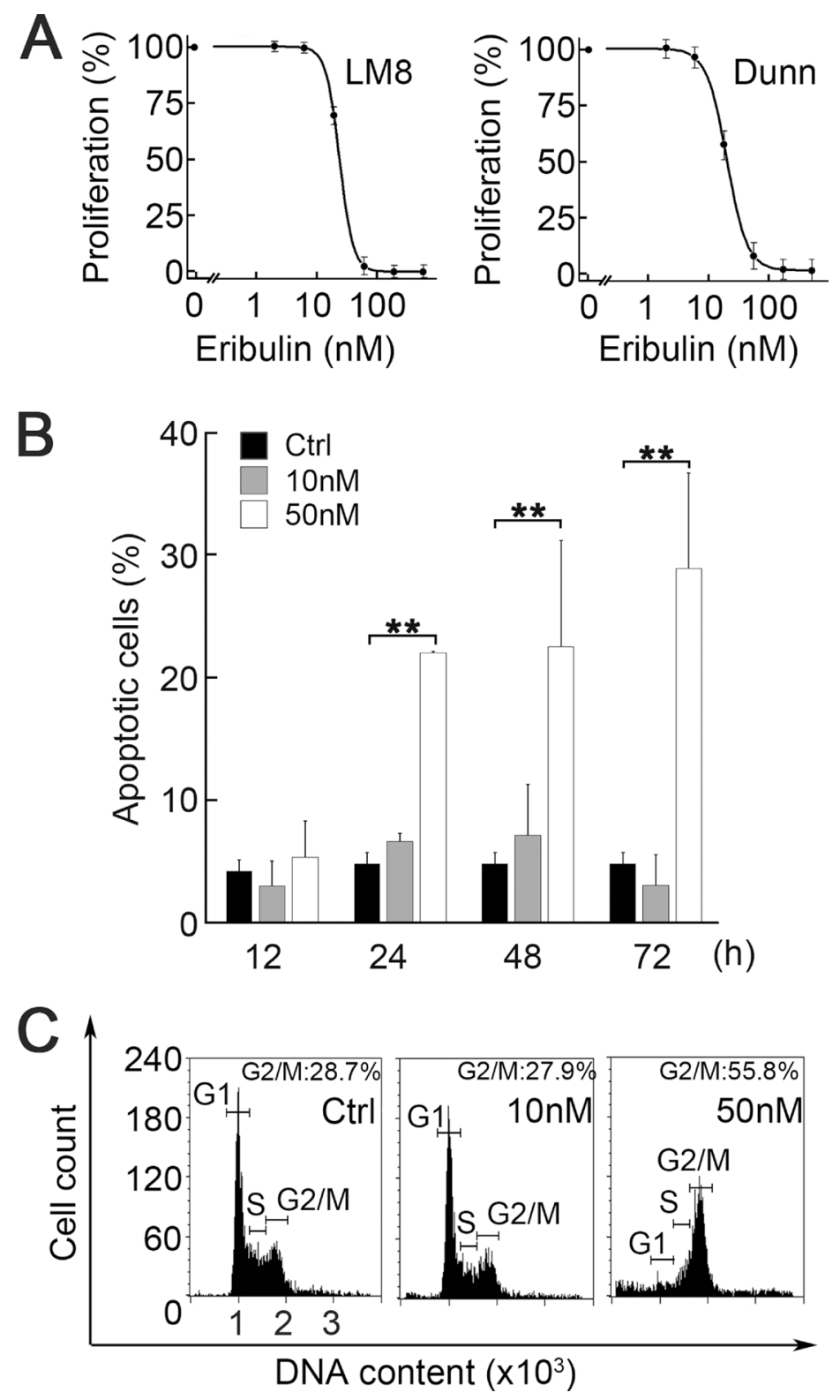

Figure 2: Effect of eribulin on cell proliferation, cell cycle, and apoptosis. (A) Dose-dependent curves of the proliferation of LM8 cells (left) and Dunn cells (right) exposed to eribulin for $72 \mathrm{~h}(n=5)$. $\mathrm{IC}_{50}$ of proliferation were $22.8 \mathrm{nM}$ (LM8) and $21.5 \mathrm{nM}$ (Dunn). Values are mean $\pm \operatorname{SEM}(n=3)$. (B) Flow cytometry of apoptosis. LM8 cells were incubated with $0 \mathrm{nM}, 10 \mathrm{nM}$, or $50 \mathrm{nM}$ eribulin for $12 \mathrm{~h}$, $24 \mathrm{~h}, 48 \mathrm{~h}$, or $72 \mathrm{~h}$. Values are mean $\pm \operatorname{SEM}(n=3)$. Early apoptosis was induced by $50 \mathrm{nM}$ eribulin. Black: control; gray: $10 \mathrm{nM}$ eribulin; white: $50 \mathrm{nM}$ eribulin. ${ }^{* *} P<0.01$. (C) Representative histograms of flow cytometry for cell cycle distribution. LM8 cells were incubated with $0 \mathrm{nM}, 10 \mathrm{nM}$, or $50 \mathrm{nM}$ eribulin for $12 \mathrm{~h}$. G2/M arrest was induced by $50 \mathrm{nM}$ eribulin. 
We focused on cell morphology and motility since important biological signatures of metastatic LM8 cells are their high motility and protrusive morphology [30]. Immunofluorescence imaging showed that low eribulin concentrations cause round cell morphology and reduce protrusions (Figure 3A). Imaging revealed significant decreases in protrusion formation (Figure $3 \mathrm{~B}$ ) and tubulin polymerization (Figure $3 \mathrm{C}$ ). We also investigated the suppressive effect of eribulin on cell migration using modified Boyden chamber cell migration and wound healing assays. Low eribulin concentrations effectively suppressed cell migration (Figure 3D).

\section{Reduction of directionality and focal adhesion turnover with low eribulin concentrations}

LM8 cells have higher directionality and activated focal adhesion turnover during migration than Dunn cells [30]. To determine how low eribulin concentrations suppress LM8 migration, we examined cell directionality during wound healing. Cells oriented for migration were defined as those with microtubule-organizing centers (MTOC) localized in the $120^{\circ}$ sector facing the wound edge (Supplementary Figure 4). The number of oriented cells was significantly lower in cells for the eribulin treatment than the control (Figure 4A). We also examined the effect of low eribulin concentrations on focal adhesion turnover. Immunofluorescence imaging revealed that eribulin treatment enhanced vinculin staining in a dose-dependent manner (Figure 4B, left). Eribulin significantly increased the area stained by vinculin relative to the control. Therefore, focal adhesions enlarged as focal adhesion turnover decreased (Figure 4B, right). Focal adhesion kinase (FAK) is a key regulator of focal adhesion dynamics and autophosphorylation at the Tyr397 site promotes focal adhesion turnover. LM8 cells in the control group showed strong staining with phosphorylated FAK (pFAK) at the peripheral sites of
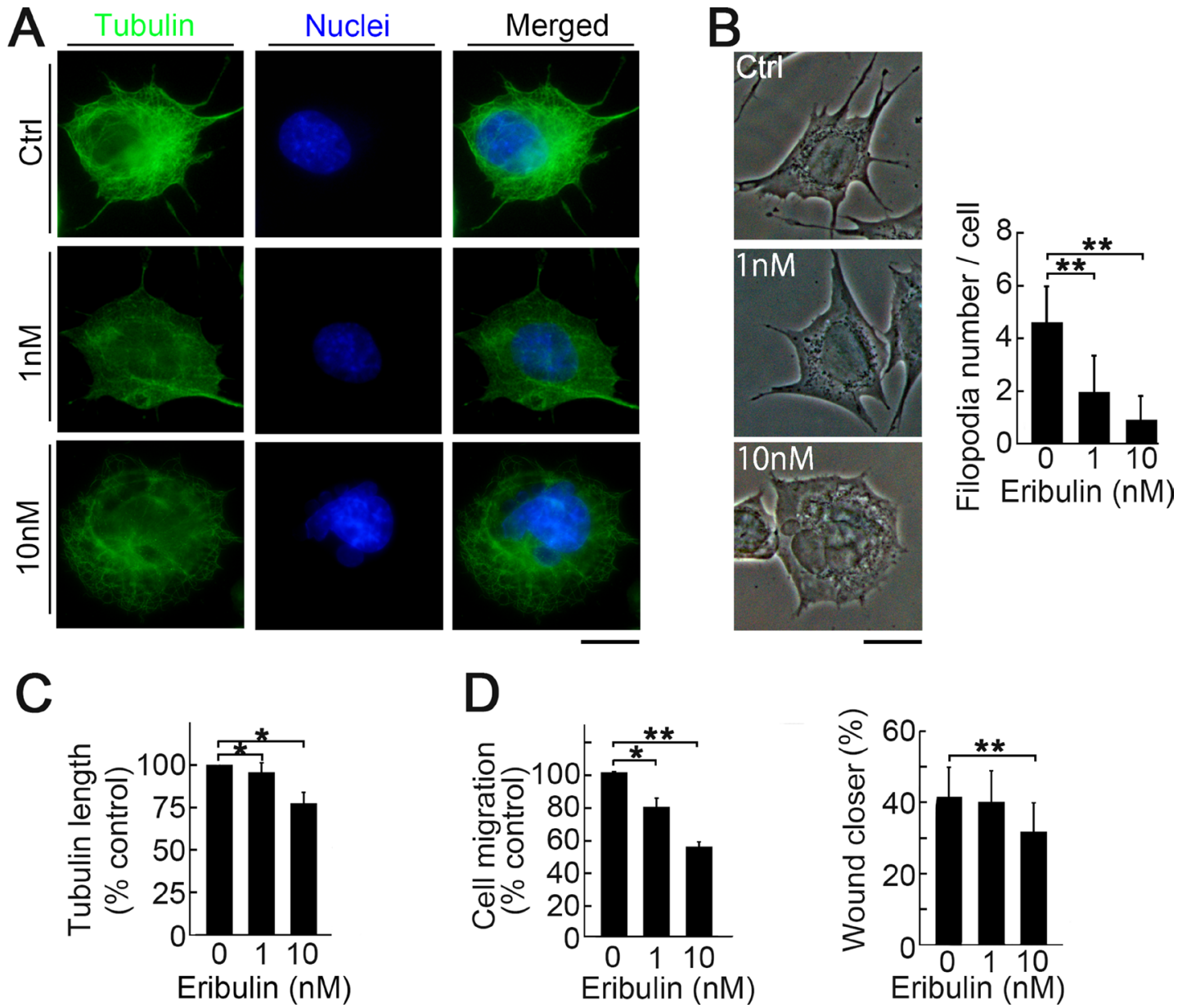

Figure 3: Induction of morphological change and suppression of migration by low eribulin concentrations. (A) Immunofluorescent images of LM8 cells stained for $\alpha$-tubulin (green) and nucleus (blue). LM8 cells were treated with eribulin for 16 h. LM8 cells became round and lost their cell protrusions. Scale bar: $10 \mu \mathrm{m}$. (B) Phase-contrast images showing dose-dependent changes in the morphology of LM8 cells treated with eribulin (left). Number of protrusions on LM8 cells (right). Values are mean \pm SEMs ( $\geq 30$ cells per group). ${ }^{* * *} P<0.01$. (C) Length of $\alpha$-tubulin. Values are mean \pm SEM ( $\geq 30$ cells per group). ${ }^{* *} P<0.01 ;{ }^{*} P<0.05$. (D) Percentage of migrated cells for the modified Boyden chamber migration (left) and wound healing (right) assays. Values are mean $\pm \operatorname{SEM}(n=3){ }^{*} P<$ $0.05 ;{ }^{* *} P<0.01$. Eribulin suppressed LM8 cell migration in both assays. 
the cells. Eribulin decreased this staining in a dosedependent manner (Figure 4C, left). Imaging showed that eribulin significantly reduced pFAK staining at the cell periphery (Figure $4 \mathrm{C}$, right). Reduction of FAK phosphorylation was also confirmed by western blotting (Figure 4D). Recent evidence has shown that three major microtubule-associated proteins-adenomatous polyposis coli (APC), MACF1/ACF7, and cytoplasmic linker-associated proteins (CLASPs) - are involved in microtubule interaction with focal adhesions. Among them, APC is involved in focal adhesion turnover and cell migration [31-35]. Immunofluorescence imaging showed that APC distribution extended to the cell periphery and partially colocalized with focal adhesions in LM8 cells (Figure 4E, top). Eribulin clearly suppressed the peripheral localization of APC (Figure 4E, middle and bottom). The inhibition of APC intracellular transport to the cell periphery by eribulin decreased focal adhesion turnover. At high concentrations, eribulin induced cell cycle arrest and cell death, whereas at low concetrations it reduced cell motility by suppressing focal adhesion turnover and directionality. Both of these contributed to reduced metastasis (Supplementary Figure 5).

\section{Inhibition of invasion and colony formation in collagen gels by low eribulin concentrations}

To mimic the effect of eribulin on metastatic tumor cell engraftment in the soft lung tissue, we used a very soft three-dimensional (3D) collagen culture system. Figure 5A shows invadopodia shrinkage (top) and colony size reduction (bottom) by eribulin. Imaging indicated that eribulin significantly decreased invadopodia length (Figure 5B) and colony size (Figure 5C). We also counted the total cell and colony numbers per gel. At $10 \mathrm{nM}$, eribulin significantly decreased the total cell number. Therefore, the $\mathrm{IC}_{50}$ concentration of eribulin in $3 \mathrm{D}$ culture might be lower than that in two-dimensional (2D) culture on a plastic plate (Figure 5D). Low eribulin concentrations also decreased the colony formation rate (colony number on day 4/applied cell number on day 0) (Figure 5E). The decreases in proliferation and colony formation with eribulin in the $3 \mathrm{D}$ collagen culture system might reflect reduced metastatic tumor cell engraftment in the lung.

\section{Frequent low-dose eribulin administration reduced lung metastasis and CTC}

The anti-metastatic effects of low eribulin concentrations inspired us to explore a new mode of administration with relatively fewer side effects, in which eribulin pharmacokinetics presented a lower peak in the high-concentration phase and a longer duration in the lowconcentration phase compared to those observed with the standard treatment schedule. We examined the effect of frequent low-dose eribulin adminstration $(0.3 \mathrm{mg} / \mathrm{kg}$ every
4 days $\times 4)$. The total eribulin dose was reduced to $60 \%$ of that of $1 \mathrm{mg} / \mathrm{kg}$ every 7 days $\times 2$ (Figure $6 \mathrm{~A}$ ). As expected, frequent low-dose eribulin administration avoided severe body weight loss (Figure 6B). The average size of the primary tumors in the treatment group was similar to that in the control group (Figure 6C). In contrast, frequent low-dose eribulin administration significantly reduced lung metastasis and CTC number to almost the same level as that observed with the standard eribulin treatment schedule (Figure 6D-6F).

\section{DISCUSSION}

In this study, we showed that eribulin was antimetastatic even at lower concentrations than the $\mathrm{IC}_{50}$ of proliferation. Low eribulin concentrations suppressed cell migration, decreased focal adhesion turnover, and reduced colony formation in 3D collagen gels. It is widely accepted that increased tumor cell migration followed by increased CTCs in blood accelerate metastasis progression [7]. We have also reported that increased cell migration and CTCs correlate with osteosarcoma lung metastasis $[30,36]$. The suppressive effects of low eribulin concentrations on these mechanisms may have led to metastasis reduction. We confirmed that frequent low-dose eribulin administration reduced lung metastasis but did not inhibit primary tumor growth.

Studies of the anticancer action of microtubule inhibitors have focused mainly on mitotic arrest and cellkilling effects [10-12]. The reduction of lung metastasis by frequent low-dose eribulin administration suggests that the development of microtubule targeting agents as metastatic inhibitors should focus on cell migration, directionality, and tumor vasculature modulation rather than mitosis. Eribulin has a novel anti-migratory mechanism through APC retention in the cell center. Anti-microtubule agents are also anti-angiogenic but their mode of action in this capacity has not yet been elucidated. Nonetheless, eribulin may remodel tumor vasculature and reduce hypoxia in the tumor microenvironment [18]. In the present study, however, we could not determine the effects of eribulin on tumor vasculature because our murine osteosarcoma model seldom showed any vasculature in the primary tumors.

Recent evidence has shown that alternative treatment strategies that administer minimum doses of drugs to maintain tumor stability (metronomic therapy or adaptive therapy) might be more effective for patient survival with metastatic disease rather than the traditional treatment targeting maximal cell death [3739]. The clinical use of eribulin is limited to single agent administration for a short period due to the occurrence of side effects. Our results showed that frequent low doses of eribulin inhibited metastasis without inducing any severe side effects. Therefore, eribulin has cytostatic action and future metronomic chemotherapies could include 


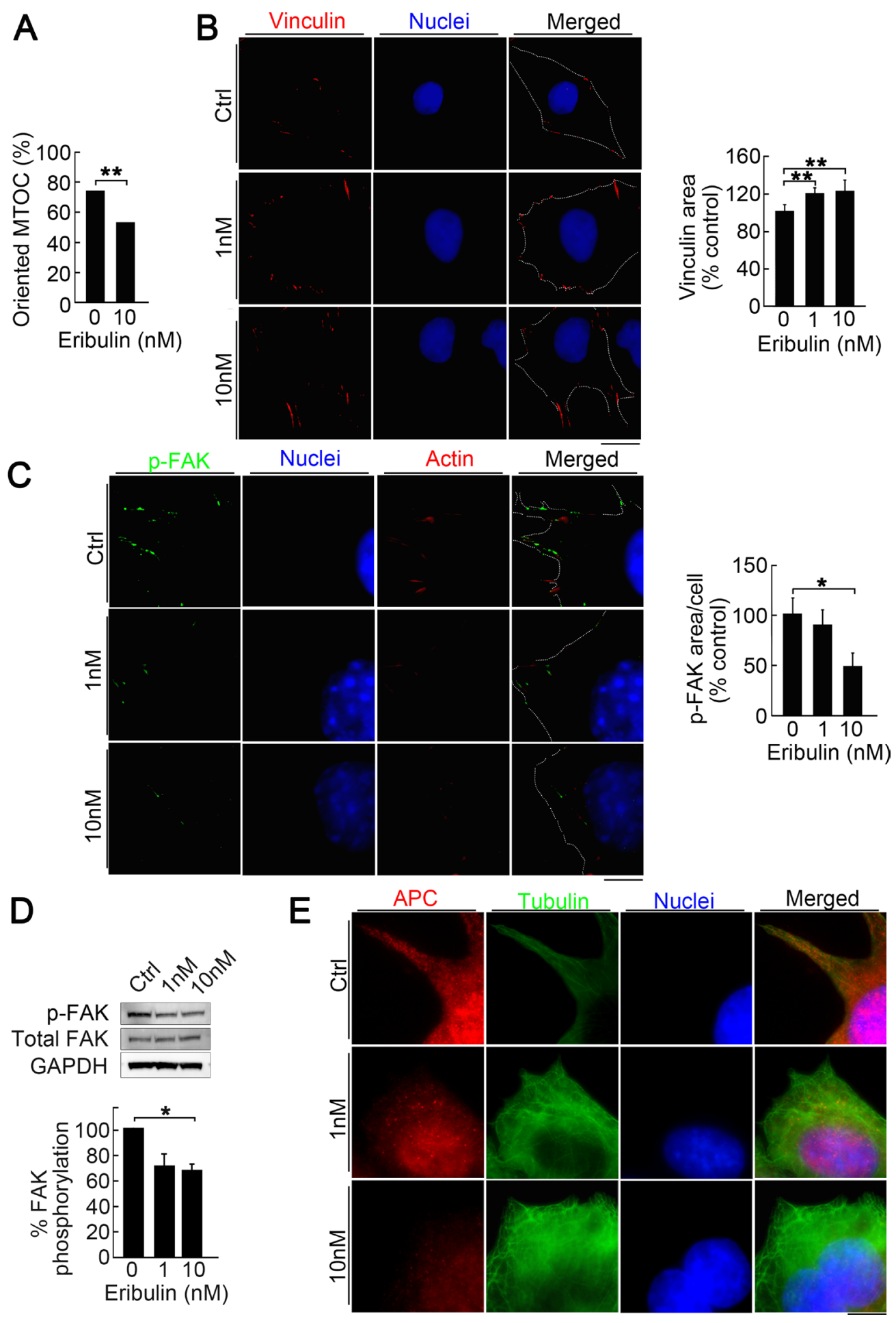

Figure 4: Reduction of directionality and focal adhesion turnover by low eribulin concentrations. (A) Effect of eribulin on MTOC directionality during wound healing. Percentage of cells with MTOC facing the wound (bottom). Values are mean $\pm \operatorname{SEM}(n$ $=3)^{* *} P<0.01$. (B) immunofluorescence images of LM8 cells treated with $0 \mathrm{nM}, 1 \mathrm{nM}$, or $10 \mathrm{nM}$ eribulin and stained for vinculin (red) and nucleus (blue) (left). Dotted line shows the cell shape. Scale bar: $10 \mu \mathrm{m}$. Quantitative analysis of the area of vinculin staining (right). Values are mean \pm SEM ( $\geq 30$ cells per group). ${ }^{* *} P<0.01$. (C) Immunofluorescence images of LM8 cells treated with $0 \mathrm{nM}, 1 \mathrm{nM}$, or $10 \mathrm{nM}$ eribulin and stained for Tyr397-phosphorylated FAK (green), actin (red), and nucleus (blue) (left). Dotted line shows the cell shape. Scale bar: $10 \mu \mathrm{m}$. Quantitative analysis of the area of Tyr397-phosphorylated FAK staining (right). Values are mean \pm SEM ( $\geq 30$ cells per group). ${ }^{*} P<0.05$. Eribulin treatment shrank the Tyr397-phosphorylated FAK staining area in a dose-dependent manner. (D) Western blot of Tyr397phosphorylated FAK in LM8 cells treated with eribulin (top). Quantitative densitometric analysis of the ratio of Tyr397-phosphorylated FAK to total FAK (bottom). Values are mean $\pm \operatorname{SEM}(n=3) .{ }^{*} P<0.05$. (E) Immunofluorescence images of LM8 cells treated with $0 \mathrm{nM}$ or $10 \mathrm{nM}$ eribulin and stained for APC (red), $\alpha$-tubulin (green), and nucleus (blue). Scale bar: $10 \mu \mathrm{m}$. 
it. Combined with standard adjuvant chemotherapies, low doses of eribulin may have a long-term effect of reducing lung metastasis of osteosarcoma and may prolong the survival of osteosarcoma patients who do not have lung metastasis at first diagnosis but later develop lung metastasis. Moreover, frequent low-dose eribulin administration reduced lung metastasis but did not shrink primary tumors. Our results suggest that eribulin could be
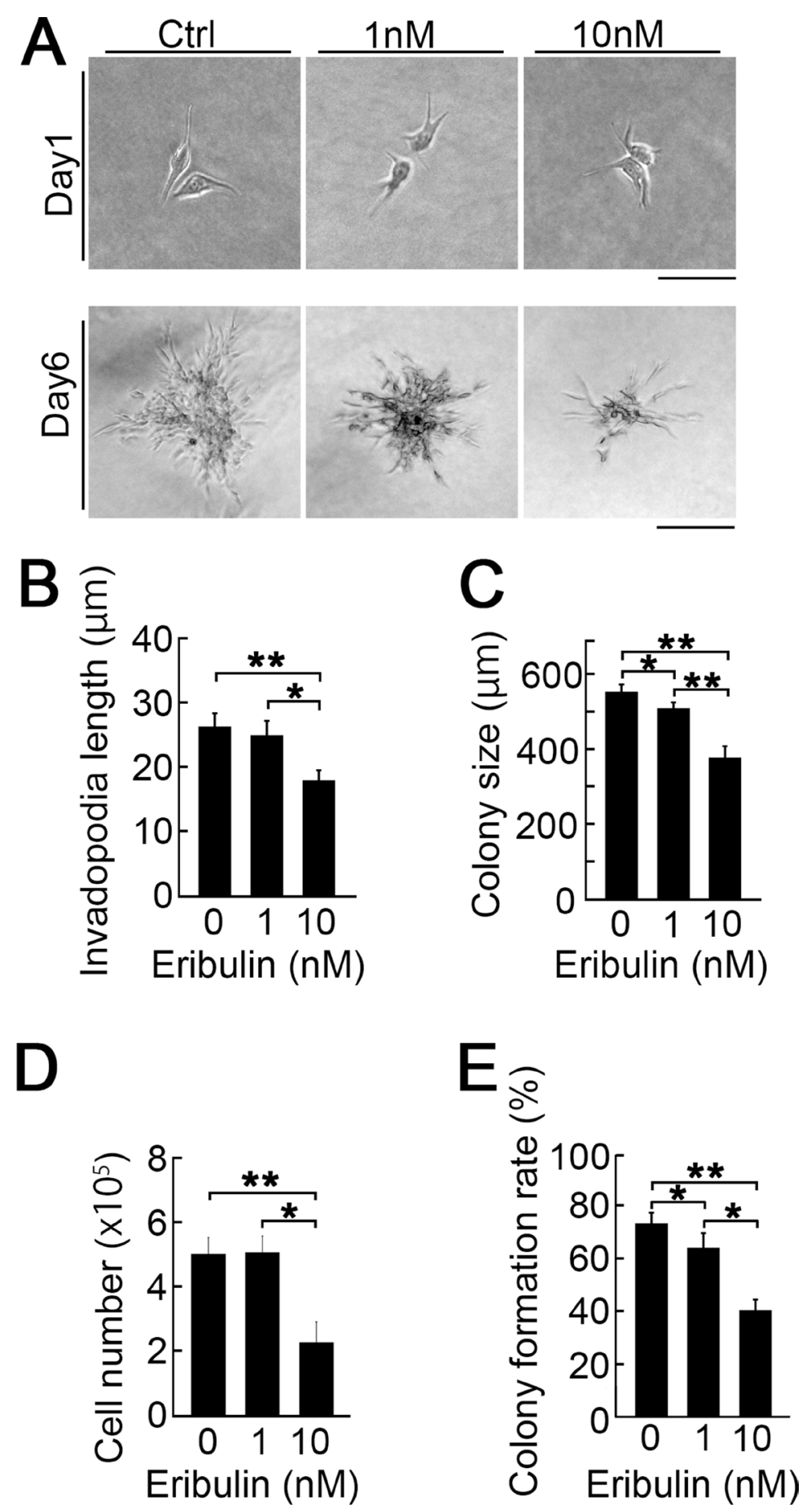

Figure 5: Effect of eribulin on the collagen 3D culture. (A) Images of LM8 cells in collagen 3D gel (1.5 mg/mL) treated with 0 $\mathrm{nM}, 1 \mathrm{nM}$, and $10 \mathrm{nM}$ eribulin on days 1 (top) and 6 (bottom). Scale bars: $40 \mu \mathrm{m}$ and $100 \mu \mathrm{m}$, respectively. (B) Quantitative analysis of invadopodia length on day 1 . Values are mean \pm SEM ( $\geq 30$ cells per group). Invadopodia shortened in a dose-dependent manner. ${ }^{*} P<0.05$; ${ }^{* *} P<0.01$. (C) Quantitative analysis of colony size on day 6. Values are mean \pm SEM ( $\geq 30$ colonies per group). Colony size decreased in a dose-dependent manner. ${ }^{*} P<0.05 ;{ }^{* *} P<0.01$. (D) Quantitative analysis of LM8 cell number in collagen $3 \mathrm{D}$ gels treated with $0 \mathrm{nM}, 1 \mathrm{nM}$, or $10 \mathrm{nM}$ eribulin. Values are mean \pm SEM ( $\geq 10$ gels per group). ${ }^{*} P<0.05 ;{ }^{* *} P<0.01$. (E) Quantitative analysis of colony formation rate (colony number on day 4 /applied cell number on day 0 ). Values are mean $\pm \operatorname{SEM}\left(\geq 10\right.$ gels per group). ${ }^{*} P<0.05 ;{ }^{* *} P<0.01$. 


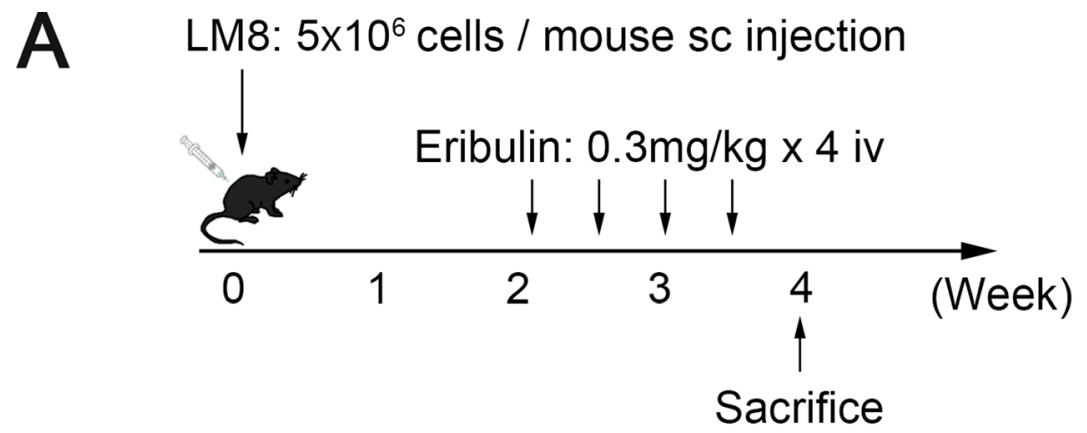

B
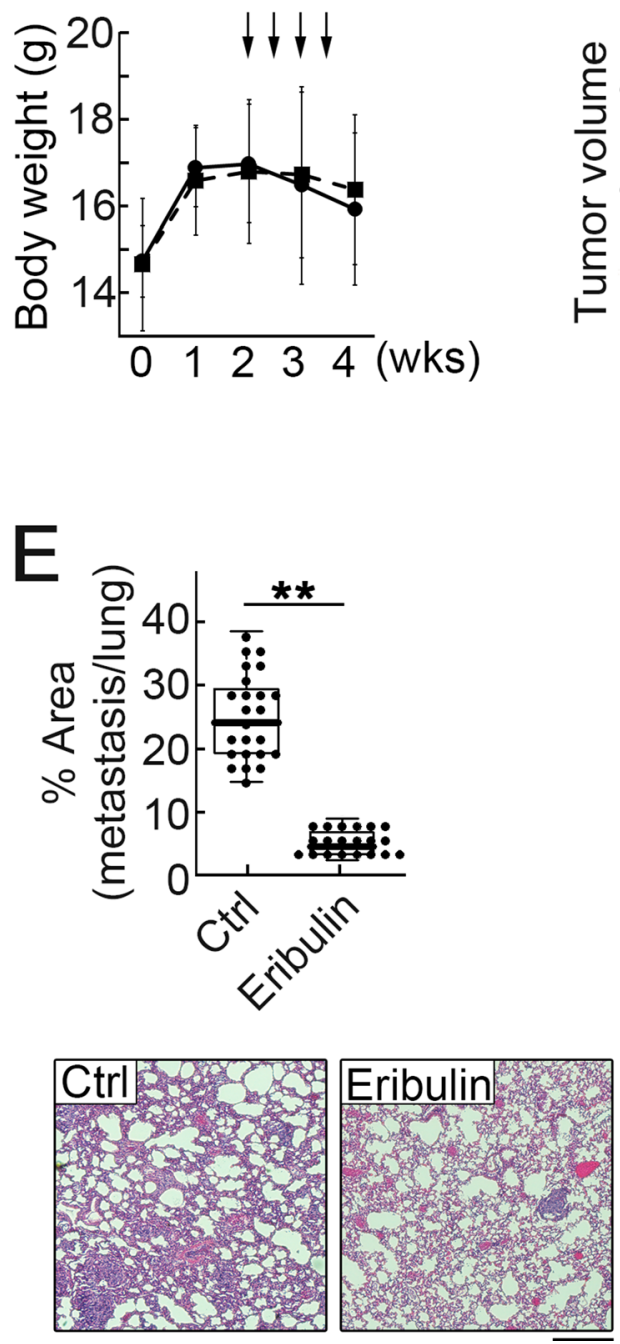
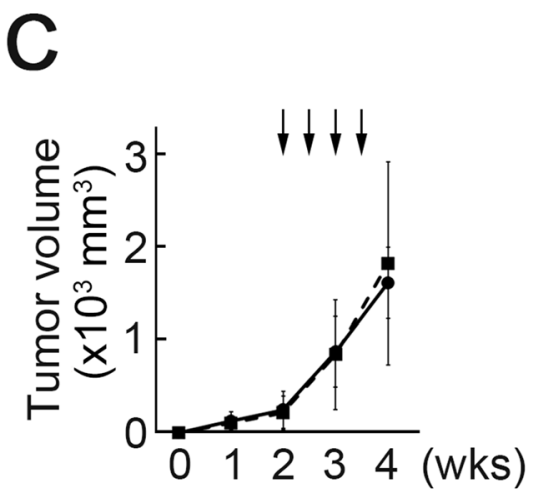

D

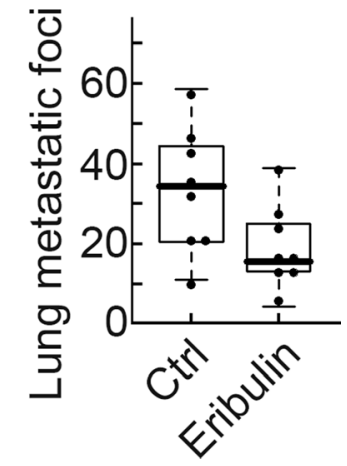

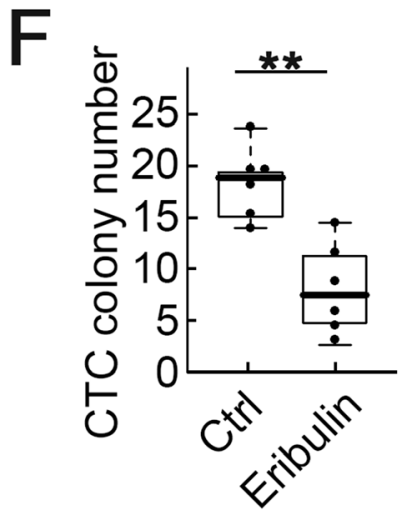

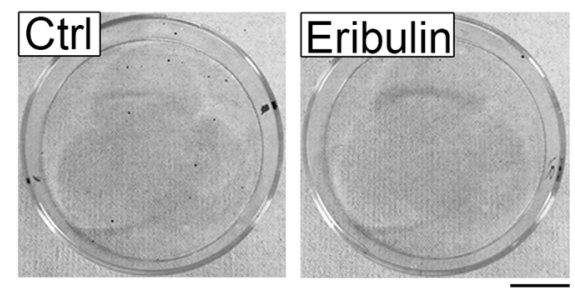

Figure 6: Low-dose eribulin inhibited pulmonary metastasis and CTC colony number. (A) Experimental schedule. Fifteen mice were divided into two groups: 1) untreated controls (seven mice); 2) models treated with eribulin at $0.3 \mathrm{mg} / \mathrm{kg} \times 2 \mathrm{per}$ week for two weeks (eight mice). (B) Body weights of the mice in the control (dotted line) and treatment (solid line) groups. Values are mean \pm SEM $(n=5)$. (C) Primary tumor growth did not significantly differ between the control and treatment groups. Arrows: injection of PBS or eribulin. Values are mean $\pm \operatorname{SEM}(n=5)$. Solid line: treatment group; dotted line: control group. (D) Number of metastatic foci in lungs was significantly lower in the treatment than in the control group. Median, quartiles, and highest and lowest values are indicated in the box-andwhisker plots. ${ }^{*} P<0.05$. (E) Ratio of metastasis area to total lung area was significantly lower in the treatment than in the control group. Median, quartiles, and highest and lowest values are indicated in the box-and-whisker plots (top). Representative H\&E-stained sections of pulmonary metastasis in the control (bottom left) and treatment (bottom right) groups are shown. Scale bar: $500 \mu \mathrm{m} .{ }^{* *} P<0.01$. (F) CTC colony number per $40 \mu \mathrm{L}$ of peripheral blood. Median, quartiles, and highest and lowest values are indicated in the box-and-whisker plots (top). Images of CTC colonies in the control (bottom left) and treatment (bottom right) groups. Scale bar: $1 \mathrm{~cm} .{ }^{* *} P<0.01$. 
used in anti-metastatic treatments for other tumors with high $\mathrm{IC}_{50}$ concentrations against eribulin but not heretofore indicated for eribulin treatment.

Few new agents evaluated in phase II studies have shown any efficacy in patients with refractory osteosarcoma. One possible explanation for these disappointing outcomes is that most phase II studies evaluate drug efficacy by primary tumor radiography, and calcification masks primary tumor shrinkage [5]. Our results show that the tumor cells at the metastatic site responded differently to anticancer agents than those in primary tumors because of the heterogeneity of the tumor cells, microenvironments, and drug delivery systems between primary- and metastatic sites. New preclinical and phase II evaluations focusing on metastasis reduction are needed to advance progress in osteosarcoma treatment. The anti-metastatic effects of other microtubule-targeting agents, such as taxanes, paclitaxel, and docetaxel, on osteosarcoma lung metastasis should be assessed despite the fact that they have proven ineffective in osteosarcoma phase II studies [40, 41].

Our study has several limitations. We used $\mathrm{C} 3 \mathrm{H}$ mice for our syngeneic metastasis model, however, the pharmacokinetics data we referred to in this study were measured using different strains (BALB/c and CF-1). We assume that the pharmacokinetics of eribulin in $\mathrm{C} 3 \mathrm{H}$ mice is similar to that in other strains as most eribulin is excreted into the bile and urine without being metabolized after intravenous injection. Sampson et al. reported that some osteosarcoma cell lines regrew in the presence of eribulin, but remained sensitive to eribulin [42]. We did not examine the delayed growth of LM8 cells at metastatic sites. It is possible that lung metastasis of LM8 proliferate later during long-term administration of eribulin, therefore, we need to examine a combination strategy with other chemotherapeutic agents.

Collectively, eribulin is a potential therapeutic option for lung metastasis of osteosarcoma. Its antimetastatic effects at concentrations lower than $\mathrm{IC}_{50}$ suggest that it has a wide application range. Frequent low-dose eribulin administration can reduce lung metastasis for a long time with relatively few side effects.

\section{MATERIALS AND METHODS}

\section{Ethics statement}

This study was conducted in accordance with the ethical standards of the Declaration of Helsinki and according to national and international guidelines and has been approved by the institutional animal experiments review committee (protocol number 29-3-\#2).

\section{Cell culture}

Mouse osteosarcoma cell lines LM8 and Dunn were kindly provided by T. Ueda (Osaka National Hospital,
Osaka, Japan). The highly metastatic osteosarcoma cell line LM8 was derived from the non-metastatic murine osteosarcoma cell line Dunn osteosarcoma by repeating eight cycles of the procedure described by Poste and Fidler [43]. The cells were maintained in Dulbecco's Modified Eagle's Medium (DMEM) supplemented with $10 \%$ fetal bovine serum (FBS) and cultured at $37^{\circ} \mathrm{C}$ in a fully humidified incubator under $5 \% \mathrm{CO}_{2}$. All cells were passaged for one month ( $<15$ passages) for the in vitro and in vivo experiments. All cells were routinely tested for Mycoplasma contamination with the CycleavePCR Mycoplasma Detection Kit (TaKaRa Bio Inc., Kusatsu, Shiga, Japan). None of the cell lines used in this article are listed in the International Cell Line Authentication Committee or the NCBI biosample database of misidentified cell lines.

\section{Antibodies and reagents}

Eribulin was obtained from Eisai Co. Ltd. (Tokyo, Japan) through a Material Transfer Agreement. Anti- $\alpha-$ tubulin (DM1A, ab7291), anti-pericentrin (ab4448), and anti-Tyr397-phosphorylated FAK (p-FAK, EP2160Y, ab81298), Goat Anti-Mouse IgG (Alexa Fluor ${ }^{\circledR}$ 488, ab150113), Donkey Anti-Rabbit IgG (Alexa Fluor ${ }^{\circledR}$ 555, ab150062), and Donkey Anti-Mouse IgG (Alexa Fluor $^{\circledR}$ 555, ab150110) were purchased from Abcam (Cambridge, UK). Anti-Vinculin (hVIN-1, NB600-1293) was purchased from Novus Biologicals (Littleton, CO, USA). Anti-APC (F-3, sc-9998) and anti-GAPDH (sc32233) were purchased from Santa Cruz Biotechnology, Inc. (Dallas, TX, USA). Anti-FAK (\#3285) was purchased from Cell Signaling Technology, Inc. (Danvers, MA, USA). Hoechst33342 was purchased from Invitrogen (Carlsbad, CA, USA). Rhodamine-Phalloidin (PHDR1) was purchased from Cytoskeleton, Inc. (Denver, CO, USA). Fibronectin solution (C-43050) was purchased from PromoCell GmbH (Heidelberg, Germany). Horseradish peroxidase (HRP)-anti-mouse IgG and HRP-anti-rabbit IgG were purchased from Jackson ImmunoResearch (West Grove, PA, USA).

\section{Animal experiments}

Four-week-old $\mathrm{C} 3 \mathrm{H} / \mathrm{HeN}$ mice were purchased from CLEA Japan, Inc. (Tokyo, Japan). LM8 cells metastasize to the lungs by both subcutaneous and intraosseous transplantation. We chose subcutaneous transplantation because of its high reproductivity of the metastatic process, such as CTC appearance and lung metastasis formation, compared to intraosseous transplantation. For the eribulin metastasis reduction experiments, LM8 cells $\left(5 \times 10^{6}\right.$ per mouse) were injected into the subcutaneous tissue of the backs of syngeneic mice. The animals were randomized into control and treatment groups. Eribulin was injected into the tail veins at $1 \mathrm{mg} / \mathrm{kg}$ every 7 days $\times$ 
2 or $0.3 \mathrm{mg} / \mathrm{kg}$ every 4 days $\times 4$. Histological evaluations and pulmonary metastasis foci counts were performed four weeks after tumor cell injection because tumor-bearing mice die from lung metastasis around 5 weeks after subcutaneous transplantation. Lungs were fixed with $10 \%$ formalin, embedded in paraffin, cut into $8-\mu \mathrm{m}$ sections, and stained with hematoxylin and eosin (H\&E). Apoptosis in the primary tumors was assessed by a TUNEL assay of the paraffin sections using an In Situ Cell Death Detection Kit (No. 11684795910; Roche Diagnostics, RischRotkreuz, Switzerland) according to the manufacturer's instructions.

For CTC quantification, eribulin was injected into the tail veins at a rate of $1 \mathrm{mg} / \mathrm{kg}$ two weeks after LM8 transplantation as mentioned above. Peripheral blood samples $(40 \mu \mathrm{L})$ were collected from the tail veins and maintained in DMEM supplemented with $10 \%$ FBS and penicillin $(100 \mathrm{U} / \mathrm{mL})$-streptomycin $(100 \mu \mathrm{g} / \mathrm{mL})$ to form colonies as previously described [36]. Colonies were fixed with $10 \%$ formalin, stained with crystal violet, and counted.

\section{Cell proliferation assay}

Cell viability was assessed with a CCK-8 WST assay kit (Dojindo Molecular Technologies, Inc., Kumamoto, Japan) according to the manufacturer's instructions. In brief, LM8 cells were plated in 96-well plates at $1 \times 10^{4}$ cells per well and incubated in DMEM with $10 \%$ FBS for $24 \mathrm{~h}$. Then, the cells were treated with various eribulin concentrations for $72 \mathrm{~h}$. CCK-8 reagent was then added to the medium, and the cells were further incubated for $2 \mathrm{~h}$ at $37^{\circ} \mathrm{C}$. Absorbance was measured at $450 \mathrm{~nm}$ on a plate reader (Sunrise Rainbow; Tecan Japan Co. Ltd., Kawasaki, Japan).

\section{Flow cytometry analysis}

The cells were plated in 24-well plates at a concentration of $3 \times 10^{5}$ cells per well and were grown for $24 \mathrm{~h}$. The cells were then treated with the indicated eribulin concentrations for the specified time periods. They were stained with Annexin-V and 7-aminoactinomycin D (7-AAD) to identify apoptosis and stained with propidium iodide for cell cycle analysis. The samples were analyzed in a Guava EasyCyte Plus Flow Cytometry System (Merck Millipore, Billerica, MA, USA).

\section{Immunofluorescence}

LM8 cells $\left(1 \times 10^{3}\right)$ were grown on eight-well culture slides (TOHO Corp, Tokyo, Japan) coated with fibronectin $(10 \mu \mathrm{g} / \mathrm{mL})$ and incubated for $24 \mathrm{~h}$. The cells were then treated with eribulin for $16 \mathrm{~h}$. They were fixed with $4 \%$ paraformaldehyde for $20 \mathrm{~min}$ and permeabilized with either $0.1 \%$ Triton X-100 (APC and p-FAK staining) or $0.1 \%$ Tween 20 ( $\alpha$-tubulin staining) for $10 \mathrm{~min}$ followed by blocking with $0.1 \%$ bovine serum albumin (BSA) and $0.1 \%$ Tween 20 for $60 \mathrm{~min}$ at room temperature. For vinculin staining, the cells were permeabilized at $4^{\circ} \mathrm{C}$ for 1 min with ice-cold permeabilization buffer $(\mathrm{pH}$ 6.9; $10 \mathrm{mM}$ HEPES, $50 \mathrm{mM} \mathrm{NaCl}, 3 \mathrm{mM} \mathrm{MgCl} \mathrm{m}_{2}, 0.5 \%$ Triton X-100, $300 \mathrm{mM}$ sucrose, and $1 \mathrm{mM}$ EGTA) before fixation. The cells were stained with primary antibodies ( $\alpha$-tubulin 1:500; p-FAK 1:250; APC 1:250; vinculin 1:50) overnight at $4^{\circ} \mathrm{C}$ followed by secondary antibody staining and counterstaining with Hoechst 33342 for 30 min at room temperature. For F-actin staining, the cells were incubated with rhodamine-phalloidin according to the manufacturer's instructions.

\section{Microscopy}

Cells and tissues were viewed under a phase contrast microscope (Eclipse Ti; Nikon Instruments, Melville, NY, USA) fitted with a Plan Fluor $\times 40$ objective lens (NA 0.6; Nikon Corp., Tokyo, Japan) for tissue sections and a Plan Fluor $\times 100$ objective lens (NA 1.30, oil, Nikon Corp.) for immunofluorescence. Images were processed and analyzed in Fiji/ImageJ v. 2.0.0-rc-67/1.52c (NIH, Bethesda, MD, USA). To quantify microtubule polymerization, we assumed that the length of fiber stained with tubulin represented the length of microtubules. Images stained with anti- $\alpha$-tubulin antibody were filtered with Bandpass Filter (ImageJ/Fiji plugin) and binarized with Skeletonize (ImageJ/Fiji plugin). The lengths of the skeletonized microtubule images were measured with the AnalyzeSkeleton (2D/3D) (ImageJ/Fiji plugin). Tubulin was considered to be polymerized when the average branch length was $>1.6 \mu \mathrm{m}$. Areas stained with viculin or phosphorylated FAK were measured by subtracting the immunofluorescent background with a rolling ball and binarizing the images. Regions $>0.03 \mu \mathrm{m}^{2}$ were measured.

\section{Protrusion measurement}

LM8 cells were plated in eight-well culture slides at a rate of $1 \times 10^{3}$ cells per well and grown for $24 \mathrm{~h}$. The cells were treated with eribulin and incubated for $16 \mathrm{~h}$. Microspikes $>20 \mu \mathrm{m}$ long were defined as protrusions. More than 150 cells from three biological replicates were analyzed.

\section{Migration assay}

The modified Boyden chamber migration and wound healing assays were performed as described previously [44, 45]. In brief, the modified Boyden chamber migration assay was performed for $12 \mathrm{~h}$ in 24-well Bio-Coat cell migration chambers (BD Biosciences, Franklin Lakes, NJ, USA). The lower surface of the membrane was coated with $30 \mu \mathrm{g} / \mathrm{mL}$ fibronectin for haptotactic migration. LM8 
cells were applied to the upper chamber at a rate of $1 \times 10^{4}$ cells with eribulin treatment for $12 \mathrm{~h}$. Non-migratory cells were removed from the upper surface with cotton swabs. Migrated cells were fixed in $70 \% \mathrm{v} / \mathrm{v}$ methanol, stained with crystal violet, and counted. For the wound healing assay, confluent LM8 cells were scratched and throughly washed with phosphate buffered saline (PBS) to remove detached cells and debris. They were then treated with eribulin for $12 \mathrm{~h}$. Images of wounds were measured with Fiji/ImageJ. Cell directionality was evaluated by fixing the cells during wound healing with $100 \%$ ice-cold methanol for $10 \mathrm{~min}$ at room temperature then blocking them for 30 min with PBS containing 1\% BSA and $0.1 \%$ Tween 20. MTOCs were stained with anti-pericentrin antibody $(1: 1,000)$ at $4^{\circ} \mathrm{C}$ overnight. The cells were then incubated with anti-Rabbit IgG (Alexa Fluor ${ }^{\circledR} 555$ ) and Hoechst for $30 \mathrm{~min}$ at room temperature. More than 100 cells from three separate experiments were analyzed.

\section{$3 D$ collagen culture}

Collagen gels were fabricated by diluting $3.8 \mathrm{mg} / \mathrm{mL}$ acid-solubilized rat-tail collagen (Corning Inc., Corning, $\mathrm{NY}, \mathrm{USA}$ ) in DMEM to $1.5 \mathrm{mg} / \mathrm{mL}$ and neutralizing to $\mathrm{pH}$ 7.4 with $1 \mathrm{~mol} / \mathrm{L} \mathrm{NaOH}$. Cell suspensions were added to the wells at a density of 200 cells/well then immediately transferred to a $37^{\circ} \mathrm{C}$ incubator for $30 \mathrm{~min}$ to initiate polymerization. The collagen gels were then covered with culture media containing eribulin. Cells or colonies were observed under a microscope on days 1, 4, and 6 . Invadopodia lengths and colony sizes were analyzed using the Fiji/ImageJ software. Colony formation rates were calculated as the colony numbers on day 4 per applied cell number.

\section{Statistical analysis}

Pairs of groups were compared using a two-tailed unpaired Student's $t$-test. Three groups were compared by one-way ANOVA. Comparisons between groups were made with a Tukey-Kramer multiple comparisons test. All statistical analyses were performed with the Statcel v. 3 (OMS Publishing Inc., Tokyo, Japan) add-in for Microsoft Excel (Microsoft Corp., Redmond, WA, USA). Values $<0.05$ were considered statistically significant. Error bars for all figures represent the standard error of the mean (SEM), unless otherwise stated. Data for in vitro experiments represent $\geq 3$ independent biological experiments.

\section{Abbreviations}

CTC, circulating tumor cell; MTA, microtubule targeting agent; MTOC, microtubule-organizing center; FAK, focal adhesion kinase; APC, adenomatous polyposis coli; 3D, three-dimensional; 2D, two-dimensional; DMEM, Dulbecco's Modified Eagle's Medium; FBS, fetal bovine serum; BSA, bovine serum albumin; PBS, phosphate buffered saline.

\section{Author contributions}

YY and SS designed the experiments; KW and YY performed the experiments and analyzed data; KW, YY, and SS wrote the manuscript; KS, MK, TY, and TK advised on experimental design and provided critical feedback; all authors reviewed the manuscript.

\section{ACKNOWLEDGMENTS}

The authors thank Eisai Inc. for providing eribulin. We thank Hidemitsu Nakagawa, Tomoyuki Yamaguchi, Masashi Kishi, and Toshie Shinagawa for their helpful comments. We also thank Editage (www.editage.jp) for English language editing.

\section{CONFLICTS OF INTEREST}

The authors declare that there are no potential conflicts of interest.

\section{FUNDING}

This work was supported by JSPS KAKENHI Grant Number JP18K16641.

\section{REFERENCES}

1. Kansara M, Teng MW, Smyth MJ, Thomas DM. Translational biology of osteosarcoma. Nat Rev Cancer. 2014; 14:722-35. https://doi.org/10.1038/nrc3838.

2. Friebele JC, Peck J, Pan X, Abdel-Rasoul M, Mayerson JL. Osteosarcoma: A Meta-Analysis and Review of the Literature. Am J Orthop (Belle Mead NJ). 2015; 44:547-53.

3. Link MP, Goorin AM, Horowitz M, Meyer WH, Belasco J, Baker A, Ayala A, Shuster J. Adjuvant chemotherapy of high-grade osteosarcoma of the extremity. Updated results of the Multi-Institutional Osteosarcoma Study. Clin Orthop Relat Res. 1991; 8-14.

4. Rosen G, Caparros B, Huvos AG, Kosloff C, Nirenberg A, Cacavio A, Marcove RC, Lane JM, Mehta B, Urban C. Preoperative chemotherapy for osteogenic sarcoma: selection of postoperative adjuvant chemotherapy based on the response of the primary tumor to preoperative chemotherapy. Cancer. 1982; 49:1221-30.

5. Isakoff MS, Bielack SS, Meltzer P, Gorlick R. Osteosarcoma: Current Treatment and a Collaborative Pathway to Success. J Clin Oncol. 2015; 33:3029-35. https://doi.org/10.1200/JCO.2014.59.4895.

6. Steeg PS. Targeting metastasis. Nat Rev Cancer. 2016; 16:201-18. https://doi.org/10.1038/nrc.2016.25. 
7. Bravo-Cordero JJ, Hodgson L, Condeelis J. Directed cell invasion and migration during metastasis. Curr Opin Cell Biol. 2012; 24:277-83. https://doi.org/10.1016/j. ceb.2011.12.004.

8. Massagué J, Obenauf AC. Metastatic colonization by circulating tumour cells. Nature. 2016; 529:298-306. https://doi.org/10.1038/nature17038.

9. Khanna C, Fan TM, Gorlick R, Helman LJ, Kleinerman ES, Adamson PC, Houghton PJ, Tap WD, Welch DR, Steeg PS, Merlino G, Sorensen PH, Meltzer P, et al. Toward a drug development path that targets metastatic progression in osteosarcoma. Clin Cancer Res. 2014; 20:4200-09. https:// doi.org/10.1158/1078-0432.CCR-13-2574.

10. Mukhtar E, Adhami VM, Mukhtar H. Targeting Microtubules by Natural Agents for Cancer Therapy. Mol Cancer Ther. 2014; 13:275-84. https://doi.org/10.1158/1535-7163.MCT13-0791.

11. Jordan MA, Wilson L. Microtubules as a target for anticancer drugs. Nat Rev Cancer. 2004; 4:253-65. https:// doi.org/10.1038/nrc1317.

12. Jordan MA, Kamath K. How do microtubule-targeted drugs work? An overview. Curr Cancer Drug Targets. 2007; 7:730-42.

13. Smith JA, Wilson L, Azarenko O, Zhu X, Lewis BM, Littlefield BA, Jordan MA. Eribulin Binds at Microtubule Ends to a Single Site on Tubulin To Suppress Dynamic Instability. Biochemistry. 2010; 49:1331-7. https://doi. org/10.1021/bi901810u.

14. Swami U, Shah U, Goel S. Eribulin in Cancer Treatment. Mar Drugs. 2015; 13:5016-58. https://doi.org/10.3390/ md13085016.

15. Dumontet C, Jordan MA. Microtubule-binding agents: a dynamic field of cancer therapeutics. Nat Rev Drug Discov. 2010; 9:790-803. https://doi.org/10.1038/nrd3253.

16. Towle MJ, Salvato KA, Budrow J, Wels BF, Kuznetsov G, Aalfs KK, Welsh S, Zheng W, Seletsky BM, Palme MH, Habgood GJ, Singer LA, Dipietro LV, et al. In vitro and in vivo anticancer activities of synthetic macrocyclic ketone analogues of halichondrin B. Cancer Res. 2001; 61:1013-21.

17. Jordan MA, Kamath K, Manna T, Okouneva T, Miller HP, Davis C, Littlefield BA, Wilson L. The primary antimitotic mechanism of action of the synthetic halichondrin E7389 is suppression of microtubule growth. Mol Cancer Ther. 2005; 4:1086-95. https://doi.org/10.1158/1535-7163.MCT-04-0345.

18. Funahashi Y, Okamoto K, Adachi Y, Semba T, Uesugi M, Ozawa Y, Tohyama O, Uehara T, Kimura T, Watanabe H, Asano M, Kawano S, Tizon X, et al. Eribulin mesylate reduces tumor microenvironment abnormality by vascular remodeling in preclinical human breast cancer models. Cancer Sci. 2014; 105:1334 42. https://doi.org/10.1111/cas.12488.

19. Dybdal-Hargreaves NF, Risinger AL, Mooberry SL. Eribulin Mesylate: Mechanism of Action of a Unique MicrotubuleTargeting Agent. Clin Cancer Res. 2015; 21:2445-52. https:// doi.org/10.1158/1078-0432.CCR-14-3252.
20. Kawano S, Asano M, Adachi Y, Matsui J. Antimitotic and Non-mitotic Effects of Eribulin Mesilate in Soft Tissue Sarcoma. Anticancer Res. 2016; 36:1553-61.

21. Harrison DJ, Geller DS, Gill JD, Lewis VO, Gorlick R. Current and future therapeutic approaches for osteosarcoma. Expert Rev Anticancer Ther. 2018; 18:39-50. https://doi.org /10.1080/14737140.2018.1413939.

22. Zhang W, Kolb EA, Gorlick R, Roth M, Gill J, Rowshan S, Erickson S, Kurmasheva R, Houghton P, Teicher B, Smith MA. Abstract 5872: Pediatric Preclinical Testing Consortium (PPTC) of eribulin in osteosarcoma (OS) patient-derived xenograft (PDX) models. Cancer Res. American Association for Cancer Research; 2018; 78:58725872. https://doi.org/10.1158/1538-7445.am2018-5872.

23. Kolb EA, Gorlick R, Reynolds CP, Kang MH, Carol H, Lock R, Keir ST, Maris JM, Billups CA, Desjardins C, Kurmasheva RT, Houghton PJ, Smith MA. Initial testing (stage 1) of eribulin, a novel tubulin binding agent, by the pediatric preclinical testing program. Pediatr Blood Cancer. 2013; 60:1325-32. https://doi.org/10.1002/pbc.24517.

24. Yoshida T, Ozawa Y, Kimura T, Sato Y, Kuznetsov G, Xu S, Uesugi M, Agoulnik S, Taylor N, Funahashi Y, Matsui J. Eribulin mesilate suppresses experimental metastasis of breast cancer cells by reversing phenotype from epithelialmesenchymal transition (EMT) to mesenchymal-epithelial transition (MET) states. Br J Cancer. 2014; 110:1497-505. https://doi.org/10.1038/bjc.2014.80.

25. Kaufman PA, Awada A, Twelves C, Yelle L, Perez EA, Velikova G, Olivo MS, He Y, Dutcus CE, Cortes J. Phase III Open-Label Randomized Study of Eribulin Mesylate Versus Capecitabine in Patients With Locally Advanced or Metastatic Breast Cancer Previously Treated With an Anthracycline and a Taxane. J Clin Oncol. 2015; 33:594601. https://doi.org/10.1200/JCO.2013.52.4892.

26. Cortes J, O’Shaughnessy J, Loesch D, Blum JL, Vahdat LT, Petrakova K, Chollet P, Manikas A, Diéras V, Delozier T, Vladimirov V, Cardoso F, Koh H, et al, and EMBRACE (Eisai Metastatic Breast Cancer Study Assessing Physician's Choice Versus E7389) investigators. Eribulin monotherapy versus treatment of physician's choice in patients with metastatic breast cancer (EMBRACE): a phase 3 openlabel randomised study. Lancet. 2011; 377:914-23. https:// doi.org/10.1016/S0140-6736(11)60070-6.

27. Schöffski P, Chawla S, Maki RG, Italiano A, Gelderblom H, Choy E, Grignani G, Camargo V, Bauer S, Rha SY, Blay JY, Hohenberger P, D'Adamo D, et al. Eribulin versus dacarbazine in previously treated patients with advanced liposarcoma or leiomyosarcoma: a randomised, open-label, multicentre, phase 3 trial. Lancet. 2016; 387:1629-37. https://doi.org/10.1016/S0140-6736(15)01283-0.

28. Sugawara M, Condon K, Liang E, DesJardins C, Schuck E, Kusano K, Lai WG. Eribulin shows high concentration and long retention in xenograft tumor tissues. Cancer Chemother Pharmacol. 2017; 80:377-84. https://doi.org/10.1007/s00280-017-3369-7. 
29. Taur JS, DesJardins CS, Schuck EL, Wong YN. Interactions between the chemotherapeutic agent eribulin mesylate (E7389) and P-glycoprotein in CF-1 abcbla-deficient mice and Caco-2 cells. Xenobiotica. 2011; 41:320-6. https://doi. org/10.3109/00498254.2010.542256.

30. Yui Y, Itoh K, Yoshioka K, Naka N, Watanabe M, Hiraumi Y, Matsubara H, Watanabe KI, Sano K, Nakahata T, Adachi S. Mesenchymal mode of migration participates in pulmonary metastasis of mouse osteosarcoma LM8. Clin Exp Metastasis. 2010; 27:619-30. https://doi.org/10.1007/ s10585-010-9352-x.

31. Mimori-Kiyosue Y, Shiina N, Tsukita S. Adenomatous polyposis coli (APC) protein moves along microtubules and concentrates at their growing ends in epithelial cells. J Cell Biol. 2000; 148:505-18.

32. Näthke IS, Adams CL, Polakis P, Sellin JH, Nelson WJ. The adenomatous polyposis coli tumor suppressor protein localizes to plasma membrane sites involved in active cell migration. J Cell Biol. 1996; 134:165-79.

33. Matsumoto S, Fumoto K, Okamoto T, Kaibuchi K, Kikuchi A. Binding of APC and dishevelled mediates Wnt5a-regulated focal adhesion dynamics in migrating cells. EMBO J. 2010; 29:1192-204. https://doi.org/10.1038/emboj.2010.26.

34. Stehbens S, Wittmann T. Targeting and transport: How microtubules control focal adhesion dynamics. J Cell Biol. 2012; 198:481-9. https://doi.org/10.1083/jcb.201206050.

35. Juanes MA, Bouguenina H, Eskin JA, Jaiswal R, Badache A, Goode BL. Adenomatous polyposis coli nucleates actin assembly to drive cell migration and microtubule-induced focal adhesion turnover. J Cell Biol. 2017; 216:2859-75. https://doi.org/10.1083/jcb.201702007.

36. Tanaka T, Yui Y, Naka N, Wakamatsu T, Yoshioka K, Araki N, Yoshikawa H, Itoh K. Dynamic analysis of lung metastasis by mouse osteosarcoma LM8: VEGF is a candidate for anti-metastasis therapy. Clin Exp Metastasis. 2013; 30:369-79. https://doi.org/10.1007/s10585-0129543-8.

37. Silva AS, Kam Y, Khin ZP, Minton SE, Gillies RJ, Gatenby RA. Evolutionary approaches to prolong progression-free survival in breast cancer. Cancer Res. 2012; 72:6362-70. https://doi.org/10.1158/0008-5472.CAN-12-2235.
38. Gnoni A, Silvestris N, Licchetta A, Santini D, Scartozzi M, Ria R, Pisconti S, Petrelli F, Vacca A, Lorusso V. Metronomic chemotherapy from rationale to clinical studies: A dream or reality? Crit Rev Oncol Hematol. 2015; 95:46-61. https://doi.org/10.1016/j.critrevonc.2015.01.008.

39. Gatenby R, Brown J. The Evolution and Ecology of Resistance in Cancer Therapy. Cold Spring Harb Perspect Med. 2018; 8:a033415. https://doi.org/10.1101/cshperspect.a033415.

40. Zwerdling T, Krailo M, Monteleone P, Byrd R, Sato J, Dunaway R, Seibel N, Chen Z, Strain J, Reaman G, Children's Oncology Group. Phase II investigation of docetaxel in pediatric patients with recurrent solid tumors: a report from the Children's Oncology Group. Cancer. 2006; 106:1821-8. https://doi.org/10.1002/cncr.21779.

41. Patel SR, Papadopoulos NE, Plager C, Linke KA, Moseley SH, Spirindonidis CH, Benjamin R. Phase II study of paclitaxel in patients with previously treated osteosarcoma and its variants. Cancer. 1996; 78:741-4. https://doi.org/10.1002/(SICI)10970142(19960815)78:4<741::AID-CNCR8>3.0.CO;2-H.

42. Sampson VB, Vetter NS, Zhang W, Patil PU, Mason RW, George E, Gorlick R, Kolb EA. Integrating mechanisms of response and resistance against the tubulin binding agent Eribulin in preclinical models of osteosarcoma. Oncotarget. 2016; 7:86594-607. https://doi.org/10.18632/ oncotarget. 13358 .

43. Asai T, Ueda T, Itoh K, Yoshioka K, Aoki Y, Mori S, Yoshikawa H. Establishment and characterization of a murine osteosarcoma cell line (LM8) with high metastatic potential to the lung. Int J Cancer. 1998; 76:418-22.

44. Sotobori T, Ueda T, Myoui A, Yoshioka K, Nakasaki M, Yoshikawa $\mathrm{H}$, Itoh $\mathrm{K}$. Bone morphogenetic protein-2 promotes the haptotactic migration of murine osteoblastic and osteosarcoma cells by enhancing incorporation of integrin betal into lipid rafts. Exp Cell Res. 2006; 312:3927-38. https://doi.org/10.1016/j.yexcr.2006.08.024.

45. Nakasaki M, Yoshioka K, Miyamoto Y, Sasaki T, Yoshikawa $\mathrm{H}$, Itoh K. IGF-I secreted by osteoblasts acts as a potent chemotactic factor for osteoblasts. Bone. 2008; 43:869-79. https://doi.org/10.1016/j.bone.2008.07.241. 